\title{
Peningkatan Hasil Belajar IPS Menggunakan Model Kooperatif Tipe Student Team Achievement Division (STAD) di Kelas V SDN 22 Batang Anai Kabupaten Padang Pariaman
}

\author{
Armita Rostia \\ SDN 22 Batang Anai Kabupaten Padang Pariaman
}

\begin{abstract}
Abstrak
Penelitian ini berawal dari kenyataan di sekolah bahwa dalam proses pembelajaran peserta didik hanya duduk, diam, dengar, dan mencatat materi yang disampaikan guru. Ini disebabkan karena guru kurang mampu menggunakan model pembelajaran yang dapat mengaktifkan peserta didik secara optimal dalam proses pembelajaran. Akibatnya peserta didik seringkali tidak bersemangat dan merasa jenuh dalam pembelajaran. Selain itu sebahagian peserta didik takut dan malu bertanya kepada guru, jika mengalami kesulitan dalam pembelajaran mereka berdiam diri saja, sehingga hasil belajarnya rendah. Untuk meningkatkan hasil belajar peserta didik dalam pembelajaran IPS dilakukan penelitian dengan menggunakan model kooperatif tipe STAD. Model kooperatif tipe STAD ini merupakan model pembelajaran yang menempatkan peserta didik dalam kelompok belajar yang beranggotakan 5 atau 6 orang peserta didik. Model pembelajaran ini dilakukan melalui enam tahap, dimulai dari penyajian materi oleh guru, kegiatan belajar kelompok, pemeriksaan hasil kerja kelompok, tes secara individual, pemeriksaan hasil tes, dan penghargaan kelompok. Metode penelitian yang digunakan adalah penelitian tindakan kelas. Penelitian ini dilakukan di kelas V SDN 22 Batang Anai Kabupaten Padang Pariaman, dengan jumlah peserta didik 27 orang. Penelitian ini dilaksanakan dua siklus. Setiap siklus terdiri dari dua kali pertemuan. Hasil penelitian ini menunjukkan bahwa aktivitas dan hasil belajar peserta didik mengalami peningkatan dari siklus I ke siklus II. Kesimpulan yang didapatkan dari penelitian adalah menggunakan model pembelajaran kooperatif tipe STAD dapat meningkatkan aktivitas dan hasil belajar peserta didik dalam pembelajaran IPS di kelas V SDN 22 Batang Anai Kabupaten Padang Pariaman.
\end{abstract}

Kata Kunci: Model Kooperatif Tipe Student Team Achievement Division (STAD), Pembelajaran IPS, hasil belajar

This is an open access article distributed under the Creative Commons Attribution License, which permits unrestricted use, distribution, and reproduction in any medium, provided the original work is properly cited. (C2017 by author and Indonesian Institute for Counseling, Education and Therapy (IICET).

\section{PENDAHULUAN}

Pembelajaran IPS merupakan salah satu mata pelajaran pada jenjang pendidikan dasar memfokuskan kajiannya pada hubungan antar manusia dan proses membantu pengembangan kemampuan dalam hubungan antar manusia. Sedangkan pengetahuan, keterampilan dan sikap yang dikembangkan melalui kajian ditujukan untuk mencapai keserasian dan keselarasan dalam kehidupan masyarakat. Mata pelajaran IPS SD tidak hanya bersifat hafalan saja tetapi dapat dimengerti dan dipahami oleh peserta didik, serta dapat menerapkan atau mempraktekkan teori 
yang dipelajarinya dalam kehidupan sehari-hari. Selain memberikan pengetahuan, guru juga harus dapat membantu peserta didik mempunyai sikap dan tingkah laku yang sesuai dengan norma-norma yang berlaku dalam masyarakat. Apabila peserta didik telah memiliki sikap yang sesuai dengan norma-norma yang ada dalam masyarakat maka setiap pribadi yang demikian akan memancarkan sinarnya dalam kehidupan baik terhadap alam sekitar, terhadap Sang Khalik maupun terhadap dirinya sendiri sebagai manusia yang hidup di alam sekitarnya. Berkenaan dengan itu terasalah betapa pentingnya pembelajaran IPS SD dalam membentuk manusia Indonesia ke jalan yang sesuai dengan nilai-nilai atau norma-norma yang ada dalam masyarakat, karena itu para guru sangat dibutuhkan dalam mengemas pembelajaran IPS dengan baik.

Mewujudkan hal di atas maka sangat dipengaruhi oleh iklim pembelajaran yang kondusif. Dalam menciptakan iklim pembelajaran yang kondusif diperlukan kemampuan dan keterampilan guru dalam memilih metode, media dan model pembelajaran yang cocok. Pemilihan model pembelajaran yang cocok akan membantu peserta didik terlibat aktif dalam proses pembelajaran dan meningkatkan gairah belajar peserta didik. Banyak model pembelajaran yang dapat dipilih oleh seorang guru dalam proses pembelajaran, salah satunya adalah model kooperatif. Model pembelajaran kooperatif adalah model pembelajaran yang menempatkan peserta didik dalam beberapa kelompok belajar. Dimana dalam kelompok tersebut peserta didik dilatih untuk saling bekerja sama dalam menyelesaikan tugas kelompoknya.

Tipe Model pembelajaran kooperatif sangat banyak, salah satunya tipe Student Team Achievement Division (STAD). Sebagai salah satu tipe dari kooperatif, tipe STAD tidak jauh berbeda dengan tipe lainnya yaitu mengutamakan kerja sama dalam kelompok. Menurut Rioseptiadi (2007:4) "Pembelajaran kooperatif tipe STAD (Student Team Achievement Division) adalah pembelajaran kooperatif di mana peserta didik belajar dengan menggunakan kelompok kecil yang anggotanya heterogen dan menggunakan lembar kegiatan atau perangkat pembelajaran untuk menuntaskan materi pembelajaran, kemudian saling membantu satu sama lain untuk memahami bahan pembelajaran melalui tutorial, kuis satu sama lain dan atau melakukan diskusi”. Berdasarkan kutipan di atas pembelajaran kooperatif tipe STAD sangat bisa meningkatkan aktivitas peserta didik dalam proses pembelajaran, karena mereka ditempatkan dalam kelompok belajar yang terdiri dari tingkat akademik dan tingkat sosial yang berbeda. Namun perbedaan tersebut bukan merupakan penghalang bagi peserta didik untuk melakukan kerja sama dalam kelompoknya. Dengan perbedaan yang ada peserta didik berusaha meningkatkan kemampuannya untuk mencapai tujuan bersama dengan cara bekerja sama. Misalnya peserta didik yang berkemampuan tinggi bisa membantu temannya yang berkemampuan rendah (tutorial) karena dalam kelompok tersebut semua anggota kelompok harus menguasai materi yang diberikan. Dengan demikian mereka dilatih untuk menjunjung tinggi norma-norma kelompok, dan membangun hubungan sosial di dalam kelompok. Penilaian model kooperatif tipe STAD berbeda dengan pembelajaran kelompok biasa, yaitu nilai kelompok diambil dari kemajuan nilai individu yang dikumpulkan. Keberhasilan seorang individu sangat menentukan sekali terhadap kemajuan kelompoknya, dan bagi kelompok yang terbaik diberi penghargaan (pujian atau hadiah). Dengan demikian seluruh peserta didik akan aktif dan termotivasi dalam pembelajaran sehingga dapat meningkatkan hasil belajarnya.

Kenyataan yang ditemukan dilapangan pada siswa kelas V SDN 22 Batang Anai Kabupaten Padang Pariaman khususnya dalam pembelajaran IPS ditemukan beberapa permasalahan, di antaranya; 1) guru masih dominan menggunakan metode ceramah dalam penyampaian materi, sehingga kurang menarik perhatian, minat dan motivasi peserta didik dalam pembelajaran. Hal ini mengakibatkan peserta didik merasa jenuh dan pasif dalam pembelajaran, 2) guru belum menitikberatkan pada pemahaman peserta didik terhadap materi pembelajaran, sehingga mempengaruhi hasil belajar peserta didik, 3) dalam pembagian kelompok, guru jarang sekali memperhatikan ke heterogenan (tingkat akademik, jenis kelamin, ras, dan etnis) peserta didik. Seperti, ada satu kelompok itu peserta didik yang tingkat akademiknya tinggi saja, dan yang rendah saja, 4) pembelajaran IPS yang seharusnya menitikberatkan pada keterampilan bersosial belum begitu nampak dalam praktek keseharian peserta didik, 5) penilaian yang diberikan dalam belajar kelompok seringkali berupa penilaian kelompok tanpa memperhatikan nilai kemajuan individu kelompok. 
Proses pembelajaran yang demikian akan mempengaruhi hasil belajar peserta didik. Ini terbukti dengan hasil belajar yang diperoleh peserta didik yang terdapat dalam kumpulan nilai ulangan harian. Nilai rata-rata dari rekapitulasi nilai ulangan harian (UH) IPS pertama peserta didik mendapat nilai rata-rata 6,6 dari 27 orang peserta didik hanya 14 orang yang mencapai standar ketuntasan yang ditetapkan sekolah yaitu 7,00. Nilai rata-rata UH 2 diperoleh 6,2, dan 11 orang peserta didik yang mencapai standar ketuntasan. Nilai rata-rata UH 3 yaitu 6,1 dan 11 orang yang mencapai standar ketuntasan. Nilai rata-rata yang diperoleh peserta didik masih jauh dari standar ketuntasan ideal yang ditetapkan oleh Badan Standar Nasional Pendidikan (BSNP) yaitu 75\%. Berdasarkan permasalahan yang dikemukakan di atas, maka rumusan masalah dalam guruan ini adalah bagaimanakah pembelajaran IPS menggunakan model Kooperatif tipe Student Team Achievement Division ( STAD ) agar dapat meningkatan hasil belajar dan aktivitas siswa?

\section{METODE}

Jenis guruan yang dilaksanakan adalah Guruan Tindakan Kelas (Classroom Action Research). Guruan ini dilaksanakan dalam dua siklus. Siklus pertama terdiri atas dua kali pertemuan dengan materi bentuk-bentuk peristiwa dalam usaha mempertahankan kemerdekaan. Sedangkan siklus kedua dilakukan satu kali pertemuan dengan materi peranan para tokoh dalam mempertahankan kemerdekaan dan cara menghargai jasa para tokoh. Guruan ini dilaksanakan di SDN 22 Batang Anai Kabupaten Padang Pariaman. Subjek dalam guruan ini adalah peserta didik kelas V SDN 22 Batang Anai Kabupaten Padang Pariaman. Prosedur Guruan yang dilakukan, dimulai dengan melakukan perencanaan, pelaksanaan, observasi, dan refleksi.

\section{HASIL}

\section{Siklus I}

\section{Perencanaan}

Sebelum pelaksanaan pembelajaran terlebih dahulu guru mempersiapkan rencana pelaksanaan pembelajaran, LKS, lembar kunci LKS, lembar evaluasi serta kunci jawaban evaluasi yang akan digunakan dalam pembelajaran. Disamping itu guru juga mempersiapkan lembar pengamatan untuk mengamati jalannya pembelajaran. Untuk penyajian materi guru juga mempersiapkan media gambar. Proses pembelajaran yang dirancang untuk mencapai indikator terdiri dari kegiatan awal, inti dan akhir, dengan menggunakan model kooperatif tipe STAD. Untuk lebih jelas dapat dilihat pada uraian langkah-langkah pembelajaran model kooperatif tipe STAD berikut ini: Kegiatan Awal dilakukan dengan mengucapkan salam, bernyanyi bersama, tanyajawab, menyampaikan tujuan. Kegiatan inti terdiri dari penyajian materi, kerja kelompok, pemeriksaan hasil kerja kelompok, tes individual, pemeriksaan hasil tes, dan penghargaan kelompok. Kegiatan akhir guru dan peserta didik menyimpulkan materi yang telah diberikan, dengan mengajukan pertanyaan-pertanyaan yang berhubungan dengan materi yang telah dipelajari.

\section{Pelaksanaan}

Pembelajaran berlangsung selama 2 jam pelajaran, dengan alokasi waktu 2 x 35 menit. Proses pelaksanaan tindakan pada pertemuan pertama difokuskan pada perjuangan para tokoh dalam pertempuran Bandung Lautan Api dan pertempuran Ambarawa dalam mempertahankan kemerderkaan. Sedangkan indikator yang akan dicapai adalah: 1) menyebutkan bentuk perjuangan bangsa Indonesia dalam mempertahankan kemerdekaan, 2) mengidentifikasi peristiwa dalam mempertahankan kemerdekaan.

\section{Kegiatan Awal}

Mengawali tindakan pembelajaran ini guru terlebih dahulu mengucapkan salam, meminta peserta didik untuk merapikan tempat duduknya, mengecek kehadiran peserta didik. Selanjutnya guru membuka skemata peserta didik dengan menyanyikan lagu Halo-halo Bandung bersama-sama. Saat menyanyikan lagu halo-halo Bandung peserta didik kurang semangat, karena banyak yang lupa syairnya. Untuk memotivasi peserta didik, guru mengiringi mereka bernyanyi dengan melakukannya berulang-ulang. Kemudian guru menanyakan kepada peserta didik tentang isi lagu yang telah dinyanyikan, seperti "anak-anak mengapa kota Bandung dikatakan kota kenangkenangan? Peserta didik sangat antusias sekali tunjuk tangan dan guru memilih beberapa orang 
peserta didik untuk menjawab pertanyaan secara bergantian. Peserta didik menjawab dengan jawaban yang berbeda contohnya "karena banyak sejarahnya Bu", karena dibakar Bu". Kemudian guru mempertegas jawanban yang benar agar tidak terjadi keraguan. Kegiatan selanjutnya guru menyampaikan tujuan pembelajaran yang akan dicapai. Adapun tujuan pembelajaran yang akan dicapai yaitu peserta didik dapat menjelaskan peristiwa-peristiwa dalam mempertahankan kemerdekaan Indonesia.

\section{Kegiatan Inti}

Kegiatan inti dimulai dengan menyampaikan materi yang akan dipelajari. Materi yang dipelajari yaitu bentuk-bentuk pertempuran yang dilakukan para pejuang dalam rangka mempertahankan kemerdekaan yaitu Bandung Lautan Api. Penyajian materi diawali dengan memajangkan gambar peristiwa terbakarnya kota Bandung, dan peserta didik memperhatikan gambar secara seksama. Setelah itu guru melakukan tanya jawab tentang gambar yang dipajang, seperti "anak-anak coba perhatikan bagaimana para pejuang kita dalam mempertahankan kemerdekaan? apa yang mereka korbankan? Peserta didik menjawab dengan jawaban yang berbeda misalnya, " pergi bertempur ke medan laga $\mathrm{Bu}$, mereka rela mengorbankan harta bendanya $\mathrm{Bu}$. Kemudian guru memberikan penegasan terhadap jawaban yang diberikan peserta didik, "jawaban anak-anak Ibu semuanya benar". Kemudian guru menjelaskan tentang penyebab terjadinya peristiwa Bandung Lautan Api dan nama-nama tokoh yang berperan dalam peristiwa tesebut. Dalam penyajian materi guru banyak melakukan tanya jawab dengan peserta didik, supaya terjadi interaksi antara guru dengan peserta didik. Dan peserta didikpun sangat bersemangat menjawab pertanyaan yang diajukan.

Setelah penyajian materi selesai, dilakukan kerja kelompok dengan membagi peserta didik dalam kelompok kooperatif. Peserta didik mendengarkan tentang pembagian kelompok dan menempati kelompok yang disampaikan. Waktu pembagian kelompok ini suasana kelas sangat ribut karena peserta didik sibuk mencari teman sekelompoknya dan mengatur tempat duduk mereka. Pembagian kelompok ini berdasarkan nilai ulangan harian IPS sebelumnya, dan berdasarkan jenis kelamin yang berbeda. sehingga Adapun pembagian kelompok dapat dilihat pada tabel dibawah ini:

Tabel 1.Pembagian Peserta Didik dalam Kelompok Kooperatif

\begin{tabular}{cccc}
\hline $\begin{array}{c}\text { Tingkat } \\
\text { kemampuan }\end{array}$ & Skor dasar & Nama peserta didik & Kelompok \\
\hline \multirow{2}{*}{ Tinggi } & 85 & Ramawati & $\mathbf{1}$ \\
& 83 & Zizi & $\mathbf{3}$ \\
& 83 & Aliya & $\mathbf{4}$ \\
& 80 & Fifiani & $\mathbf{5}$ \\
& 80 & Yolanda & $\mathbf{1}$ \\
& 78 & Defayanti & $\mathbf{2}$ \\
& 78 & Efriyanti & $\mathbf{3}$ \\
& 70 & Yarniati & $\mathbf{4}$ \\
& 68 & Visnawarni & $\mathbf{5}$ \\
& 68 & Rice & $\mathbf{5}$ \\
& 68 & Meri Norman & $\mathbf{4}$ \\
& 68 & Maijel & $\mathbf{3}$ \\
& 65 & Mirnawasni & $\mathbf{2}$ \\
& 65 & Meri wisnu & $\mathbf{1}$ \\
& 65 & Ernawati & $\mathbf{5}$ \\
& 63 & Jirman & $\mathbf{4}$ \\
& 63 & Hari weri & $\mathbf{3}$ \\
& 60 & Dirlantas & $\mathbf{2}$ \\
& 60 & Yeniwati & $\mathbf{1}$ \\
& 60 & Niqita Weli & $\mathbf{4}$ \\
\hline
\end{tabular}




\begin{tabular}{llll}
\hline & 57 & Jeri Nenglo & $\mathbf{3}$ \\
\multirow{3}{*}{ Rendah } & 57 & Risna Susilo & $\mathbf{2}$ \\
& 53 & Rian Hardianto & $\mathbf{1}$ \\
& 50 & Hardimansyah & $\mathbf{5}$ \\
\cline { 2 - 4 } & $\mathbf{4 0}$ & Herman Syahrial & $\mathbf{4}$ \\
\hline
\end{tabular}

Berdasarkan skor dasar tersebut peserta didik dibagi ke dalam 5 kelompok secara heterogen, dimana pada masing-masing kelompok terdapat peserta didik yang mempunyai kemampuan akademik rendah, sedang, dan tinggi serta variasi jenis kelamin. Dan dalam satu kelompok berjumlah 5 atau 6 orang peserta didik. Nama-nama kelompok dapat dilihat pada tabel di bawah ini:

Tabel 2. Kelompok Kooperatif Siklus I

\begin{tabular}{|c|c|c|}
\hline Nama Kelompok & Nama Peserta Didik & Skor Dasar \\
\hline \multirow[t]{5}{*}{ Anggur } & 1. Ramawati & 85 \\
\hline & 2. Zizi & 78 \\
\hline & 3. Aliya & 65 \\
\hline & 4. Fifiani & 60 \\
\hline & 5. Yolanda & 53 \\
\hline \multirow{5}{*}{ Apel } & 1. Defayanti & 83 \\
\hline & 2. Efriyanti & 78 \\
\hline & 3. Yarniati & 65 \\
\hline & 4. Visnawarni & 60 \\
\hline & 5. Rice & 75 \\
\hline \multirow[t]{5}{*}{ Jeruk } & 1. Meri Norman & 83 \\
\hline & 2. Maijel & 70 \\
\hline & 3. Mirnawasni & 68 \\
\hline & 4. Meri wisnu & 63 \\
\hline & 5. Ernawati & 57 \\
\hline \multirow[t]{6}{*}{ Mangga } & 1. Jirman & 80 \\
\hline & 2. Hari Weri & 70 \\
\hline & 3. Dirlantas & 68 \\
\hline & 4. Yeniwati & 63 \\
\hline & 5. Niqita Weli & 58 \\
\hline & 6. Habrurlah & 40 \\
\hline \multirow[t]{6}{*}{ Melon } & 1. $\quad$ Rindu jari & 80 \\
\hline & 2. Jeri Nenglo & 68 \\
\hline & 3. Risna Susilo & 68 \\
\hline & 4. Rian Hardianto & 65 \\
\hline & 5. Hardimansyah & 60 \\
\hline & 6. Herman Syahrial & 50 \\
\hline
\end{tabular}

Selanjutnya guru menjelaskan aturan-aturan dalam kerja kelompok seperti: Meminta anggota kelompok bekerja sama, mengatur meja dan kursi, serta meminta kesempatan selama sepuluh menit untuk memberi nama kelompok mereka. Menganjurkan kepada tiap-tiap kelompok bekerja berpasangan dalam kelompok. Jika peserta didik memiliki pertanyaan, mereka diminta mengajukan pertanyaan tersebut kepada teman satu kelompoknya sebelum menanyakan kepada guru.Memberi penekanan kepada peserta didik bahwa tugas dikerjakan sebaik-baiknya dan akan dinilai, mereka tidak boleh mengakhiri kegiatan belajar sebelum kegiatan berakhir. Kegiatan ini berlangsung selama lima menit.

Kegiatan selanjutnya guru membagikan LKS dan teks bacaan pada masing-masing kelompok. Setiap kelompok mendapat dua rangkap. Saat pembagian LKS dan wacana ini peserta didik berebut, karena mereka tidak sabar untuk melihatnya, kemudian guru menenangkan supaya 
mereka tidak ribut karena setiap kelompok akan dapat bagian. Setelah itu guru menugasi peserta didik untuk mendiskusikan LKS yang telah dibagikan. Saat kerja kelompok masih banyak peserta didik yang kerja sendiri-sendiri. Untuk memotivasi peserta didik agar mau bekerja sama, guru menegaskan bahwa setiap anggota kelompok harus menguasai materi atau tugas yang diberikan, maka setiap kelompok harus saling membantu. Misalnya bagi mereka yang telah paham ditugasi untuk membantu temannya yang belum paham sampai setiap anggota kelompok memahami tugas yang diberikan. Waktu kerja kelompok berlangsung guru terus mengontrol dan membimbing peserta didik.

Setelah diskusi kelompok selesai maka langkah selanjutnya melakukan kegiatan pemeriksaan hasil kerja kelompok. Guru menugasi perwakilan kelompok untuk melaporkan hasil diskusi kelompoknya, sedangkan kelompok yang lain menanggapinya. Waktu pembacaan hasil kerja kelompok masih banyak peserta didik yang tidak berani karena mereka belum terbiasa. Namun guru tetap memotivasi mereka dengan cara mencontohkannya. Setelah guru mencontohkan baru ada dua perwakilan kelompok melaporkan hasil kerja kelompoknya. Sedangkan untuk menanggapi pembacaan hasil kerja baru satu kelompok yang melakukan yaitu kelompok Anggur. Selanjutnya guru membagikan kunci jawaban LKS, dan menugasi peserta didik untuk mencocokkan jawabannya dengan kunci LKS yang dibagikan.

Selesai pemeriksaan hasil kerja kelompok guru menugasi peserta didik kembali ke tempat duduk semula dan peserta didikpun kembali ke tempat duduknya masing-masing. Suasana kelas menjadi ribut kembali karena peserta didik sibuk mengatur tempat duduknya. Selanjutnya guru mengadakan tes individual untuk mengetahui tingkat pemahaman peserta didik tentang materi Bandung Lautan Api dan pertempuran Ambarawa yang telah dipelajari. Saat tes berlangsung guru menegaskan kepada peserta didik tidak dibenarkan untuk saling membantu.

Setelah peserta didik selesai mengerjakan soal-soal tersebut, maka guru memeriksa hasil tesnya. Dalam menyelesaikan soal tes peserta didik masih mengalami kesulitan dalam menjawab soal tes, sehingga nilai yang diperoleh masih rendah. Setelah diperoleh hasil tes, maka guru menentukan skor peningkatan yang diperoleh peserta didik berdasarkan selisih antara skor dasar dengan skor tes, kemudian skor peningkatan tersebut dapat digunakan untuk menghitung poin perkembangan yang diperoleh masing-masing peserta didik.

Setelah diperoleh poin perkembangan pada masing-masing peserta didik, maka poin perkembangan tersebut dimasukkan ke dalam lembar ikhtisar kelompok. Bagi kelompok yang memperoleh poin perkembangan berdasarkan kriteria yang telah ditentukan akan mendapat penghargaan.

\section{Kegiatan Akhir}

Pada akhir pembelajaran guru membimbing peserta didik menyimpulkan materi tentang pertempuran Bandung Lautan Api dan pertempuran Ambarawa. Penyimpulan materi di lakukakan dengan mengajukan pertanyaan-pertanyaan yang berhubungan dengan materi yang telah dipelajari. Apabila ada jawaban peserta didik yang kurang tepat guru dapat meluruskannya.

\section{Pengamatan}

Hasil pengamatan pada siklus I dapat dilihat dari penilaian kelompok dan ketuntasan hasil belajar siswa. Penilaian kelompok dapat dilihat pada tabel 3 di bawah ini. Tabel 3 menunjukkan bahwa kelompok baik terdiri dari kelompok anggur, apel, dan melon. Sedangkan kelompok hebat terdiri dari kelompok jeruk dan mangga.

Tabel 3. Lembar Ikhtisar Kelompok Siklus I 


\begin{tabular}{|c|c|c|c|c|c|}
\hline $\begin{array}{c}\text { Nama } \\
\text { Kelompok }\end{array}$ & Nama Siswa & $\begin{array}{l}\text { Skor } \\
\text { Dasar }\end{array}$ & $\begin{array}{l}\text { Skor } \\
\text { Akhir }\end{array}$ & $\begin{array}{c}\text { Poin } \\
\text { Perkembangan }\end{array}$ & $\begin{array}{c}\text { Penghargaan } \\
\text { kelompok }\end{array}$ \\
\hline \multirow[t]{5}{*}{ Anggur } & Ramawati & 85 & 70 & 5 & KELOMPOK \\
\hline & Zizi & 78 & 65 & 5 & BAIK \\
\hline & Aliya & 65 & 90 & 30 & \\
\hline & Fifiani & 60 & 80 & 30 & \\
\hline & Yolanda & 53 & 70 & 30 & \\
\hline Jumlah & & & & 90 & \\
\hline Rata-rata & & & & 18 & \\
\hline \multirow[t]{5}{*}{ Apel } & Defayanti & 83 & 75 & 20 & KELOMPOK \\
\hline & Efriyanti & 78 & 80 & 20 & BAIK \\
\hline & Yarniati & 65 & 75 & 20 & \\
\hline & Visnawarni & 60 & 50 & 10 & \\
\hline & Rice & 57 & 65 & 10 & \\
\hline Jumlah & & & & 80 & \\
\hline Rata-rata & & & & 16 & \\
\hline \multirow[t]{5}{*}{ Jeruk } & Meri Norman & 83 & 75 & 20 & КЕLOMРОК \\
\hline & Maijel & 70 & 80 & 20 & HEBAT \\
\hline & Mirnawasni & 68 & 80 & 30 & \\
\hline & Meri wisnu & 63 & 60 & 10 & \\
\hline & Ernawati & 57 & 60 & 20 & \\
\hline Jumlah & & & & 100 & \\
\hline Rata-rata & & & & 20 & \\
\hline \multirow[t]{6}{*}{ Mangga } & Jirman & 80 & 85 & 20 & КЕLOMPOK \\
\hline & Hari Weri & 70 & 65 & 10 & HEBAT \\
\hline & Dirlantas & 68 & 60 & 10 & \\
\hline & Yeniwati & 63 & 80 & 30 & \\
\hline & Niqita Weli & 58 & 60 & 20 & \\
\hline & Habrurlah & 40 & 55 & 30 & \\
\hline Jumlah & & & & 120 & \\
\hline Rata-rata & & & & 20 & \\
\hline \multirow[t]{6}{*}{ Melon } & Rindu jari & 80 & 80 & 20 & KELOMPOK \\
\hline & Jeri Nenglo & 68 & 45 & 5 & BAIK \\
\hline & Risna Susilo & 68 & 60 & 10 & \\
\hline & Rian Hardianto & 65 & 65 & 20 & \\
\hline & Hardimansyah & 60 & 80 & 30 & \\
\hline & Herman Syahrial & 50 & 70 & 30 & \\
\hline Jumlah & & & & 115 & \\
\hline Rata-rata & & & & 19,2 & \\
\hline
\end{tabular}

Guru menyadari bahwa proses pembelajaran IPS pada siklus I ini belum sepenuhnya sesuai dengan perencanaan pembelajaran yang telah dibuat. Ketuntasan nilai belajar yang diharapkan masih kurang dari target yang ditetapkan. Hal ini dapat dilihat dari hasil yang diperoleh peserta didik yaitu dengan nilai rata-rata 72,2. Sedangkan ketuntasan individual hanya 48,15\%. Hal ini menunjukkan bahwa kurang dari separuh siswa belum tuntas dalam belajar. Untuk lebih jelasnya dapat dilihat pada tabel di bawah ini:

Tabel 4. Ketuntasan Belajar Peserta Didik Siklus I 


\begin{tabular}{|c|c|c|c|c|c|c|}
\hline \multirow[b]{2}{*}{ No } & \multirow[b]{2}{*}{ Nama } & \multirow[b]{2}{*}{ Nilai } & \multirow{2}{*}{$\begin{array}{c}\% \\
\text { Ketuntasan } \\
\text { Perorangan }\end{array}$} & \multicolumn{2}{|c|}{ Ketuntasan } & \multirow[b]{2}{*}{ Keterangan } \\
\hline & & & & Tuntas & $\begin{array}{l}\text { Belum } \\
\text { Tuntas }\end{array}$ & \\
\hline 1 & Ramawati & 80 & $80 \%$ & $\sqrt{ }$ & & \\
\hline 2 & Zizi & 85 & $85 \%$ & $\sqrt{ }$ & & \\
\hline 3 & Aliya & 75 & $75 \%$ & $\sqrt{ }$ & & \\
\hline 4 & Fifiani & 75 & $75 \%$ & $\sqrt{ }$ & & \\
\hline 5 & Yolanda & 90 & $90 \%$ & $\sqrt{ }$ & & \\
\hline 6 & Defayanti & 80 & $80 \%$ & $\sqrt{ }$ & & \\
\hline 7 & Efriyanti & 65 & $65 \%$ & - & $\sqrt{ }$ & \\
\hline 8 & Yarniati & 80 & $80 \%$ & $\sqrt{ }$ & & \\
\hline 9 & Visnawarni & 65 & $65 \%$ & - & $\sqrt{ }$ & \\
\hline 10 & Rice & 80 & $80 \%$ & $\sqrt{ }$ & - & \\
\hline 11 & Meri Norman & 60 & $60 \%$ & - & $\sqrt{ }$ & \\
\hline 12 & Maijel & 80 & $80 \%$ & $\sqrt{ }$ & - & \\
\hline 13 & Mirnawasni & 75 & $75 \%$ & $\sqrt{ }$ & - & \\
\hline 14 & Meri wisnu & 75 & $75 \%$ & $\sqrt{ }$ & - & \\
\hline 15 & Ernawati & 60 & $60 \%$ & - & $\sqrt{ }$ & \\
\hline 16 & Jirman & 60 & $60 \%$ & - & $\sqrt{ }$ & \\
\hline 17 & Hari weri & 80 & $80 \%$ & $\sqrt{ }$ & - & \\
\hline 18 & Dirlantas & 65 & $65 \%$ & - & $\sqrt{ }$ & \\
\hline 19 & Yeniwati & 65 & $65 \%$ & - & $\sqrt{ }$ & \\
\hline 20 & Niqita Weli & 45 & $45 \%$ & - & $\sqrt{ }$ & \\
\hline 21 & Habrurlah & 80 & $80 \%$ & $\sqrt{ }$ & - & \\
\hline 22 & Rindu jari & 60 & $60 \%$ & - & $\sqrt{ }$ & \\
\hline 23 & Jeri Nenglo & 50 & $50 \%$ & - & $\sqrt{ }$ & \\
\hline 24 & Risna Susilo & 65 & $65 \%$ & - & $\sqrt{ }$ & \\
\hline 25 & Rian Hardianto & 70 & $70 \%$ & - & $\sqrt{ }$ & \\
\hline 26 & Hardimansyah & 70 & $70 \%$ & - & $\sqrt{ }$ & \\
\hline 27 & Herman Syahrial & 55 & $55 \%$ & - & $\sqrt{ }$ & \\
\hline \multicolumn{2}{|c|}{ Jumlah } & 1950 & & & & \\
\hline \multicolumn{2}{|c|}{ Rata-rata } & 72,22 & & & & \\
\hline \multicolumn{2}{|c|}{ Persen } & $72,22 \%$ & & $48,15 \%$ & $51,85 \%$ & \\
\hline
\end{tabular}

Dari data di atas dapat diperoleh gambaran bahwa hasil pembelajaran IPS dengan menggunakan model kooperatif tipe STAD adalah sebagai berikut :angka perolehan tertinggi adalah 90 sebanyak 1 orang, nilai 85 sebanyak 1 orang, nilai 80 sebanyak 7 orang, nilai 75 sebanyak 4 orang, nilai 70 sebanyak 2 orang, nilai 65 sebanyak 5 orang, nilai 60 sebanyak 3 orang, nilai 55 sebanyak 1 orang, nilai 50 sebanyak 1 orang, dan nilai 45 sebanyak 1 orang. Sedangkan peserta didik yang tuntas baru mencapai 13 orang.

\section{Refleksi}

Hasil diskusi dan refleksi antara guru dengan kepala sekolah pada siklus pertama diketahui bahwa yang perlu diperhatikan sebagai perencanaan tindakan siklus berikutnya adalah:

1. Masih kurangnya keberanian peserta didik untuk bertanya.

2. Ketika pembagian kelompok kondisi kelas agak ribut, karena peserta didik sibuk mencari teman satu kelompoknya, serta sibuk mengatur tempat duduknya.

3. Masih ada beberapa orang peserta didik yang keberatan berada dalam kelompok yang telah dibagi.

4. Peserta didik masih ada yang suka berpikir sendiri, kurang berbagi ide denganteman satu kelompoknya.

5. Ada beberapa kelompok yang tidak mempresentasekan hasil kerja kelompoknya ke depan kelas.

6. Hasil tes siklus I menunjukkan bahwa jawaban peserta didik belum sesuai dengan apa yang 
diharapkan. Masih ada sebagian peserta didik yang mengalami kesulitan dalam menjawab soal yang dikerjakan.

Berdasarkan pengamatan, dan hasil tes maka tujuan yang diharapkan pada pembelajaran siklus I belum tercapai. Dengan demikian upaya meggunakan model kooperatif tipe STAD dapat direncanakan langkah-langkah proses pembelajaran yang akan ditargetkan pada siklus II. Dengan demikian rencana perbaikan ditargetkan pada kendala yang ditemui pada siklus I, dan akan dilaksanakan pada siklus II.

\section{Siklus II \\ Perencanaan}

Hasil refleksi pada siklus I menunjukkan bahwa untuk meningkatkan pembelajaran IPS tetap dilakukan dengan menggunakan model kooperatif tipe STAD dan sebagai bahan tambahan untuk perbaikan dari siklus I dilakukan hal-hal sebagai berikut: 1) memperjelas penyampaian tujuan pembelajaran agar peserta didik lebih memahami materi yang akan diajarkan, 2) merancang ulang cara pembagian kelompok, 3) Memberikan motivasi kepada setiap kelompok agar lebih aktif lagi dalam berdiskusi, serta terus memotivasi peserta didik agar mau mengemukakan ide dan pendapatnya dalam diskusi kelompok, 4) berusaha memaksimalkan pemakaian waktu dalam pembelajaran sesuai dengan rencana pembelajaran, 6) memperbaiki langkah-langkah pembelajaran yang tumpang tindih.

\section{Pelaksanaan}

Kegiatan Awal

Pelaksanaan kegiatan awal pada siklus II ini sama dengan siklus I. Guru meminta peserta didik untuk berdoa secara bersama-sama. Selanjutnya guru mengecek kehadiran peserta didik. Kemudian untuk membangkitkan skemata peserta didik, guru menanyakan kembali, apa bentuk perjuangan yang dilakukan para pejuang dalam mempertahankan kemerdekaan? Dan peserta didik menjawab pertanyaan, walaupun masih ada beberapa pertanyaan dengan bimbingan guru. Dari hasil tanya jawab, ternyata peserta didik masih banyak yang mengingat pelajaran yang telah dipelajari. Selanjutnya guru menyampaikan tujuan pembelajaran yang akan dicapai.

\section{Kegiatan Inti}

Pada langkah ini guru memulainya dengan memajangkan gambar para pahlawan yang berperan dalam mempertahankan kemerdekaan. Kemudian guru meminta peserta didik untuk memperhatikan gambar yang dipajang. Berdasarkan gambar yang dipajang guru menanyakan " anak-anak coba sebutkan nama-nama pahlawan yang ibu pajang ini”, anak-anak nampak bersemangat sekali menjawabnya, "ada bapak Soekarno, Jenderal Soedirman bu". Bagaimana jawabannya anak-anak? "Benar atau salah? Peserta didik menjawab dengan serentak "benar Bu" Dalam mengidentifikasi gambar ini guru terus membimbing peserta didik dengan melakukan tanya jawab dan peserta didik sangat bersemangat menjawab pertanyaan yang diajukan. Setelah dilakukan tanya jawab maka ditemukan empat orang tokoh yang berperan dalam mempertahankan kemerdekaan. Selanjutnya guru menjelaskan materi tentang para tokoh yang berperan dalam mempertahankan kemerdekaan. Saat penyajian materi ini peserta didik sangat antusias mendengarkan.

\section{Kegiatan kerja kelompok}

Selesai penyajian materi, guru membagi peserta didik dalam kelompok kooperatif dan peserta didik mendengarkan pembagian kelompok yang dibacakan. Pembagian kelompok ini berdasarkan nilai hasil tes siklus I, yang mana nilai tersebut dijadikan sebagai skor dasar. Pembagian kelompok dapat dilihat pada tabel di bawah ini:

Tabel 5. Pembagian Peserta Didik dalam Kelompok Kooperatif pada Siklus II 


\begin{tabular}{|c|c|c|c|}
\hline $\begin{array}{c}\text { Tingkat } \\
\text { Kemampuan }\end{array}$ & Skor dasar & Nama peserta didik & Kelompok \\
\hline \multirow{7}{*}{ Tinggi } & 90 & Ramawati & 1 \\
\hline & 85 & Zizi & 2 \\
\hline & 80 & Aliya & 3 \\
\hline & 80 & Fifiani & 4 \\
\hline & 80 & Yolanda & 5 \\
\hline & 80 & Defayanti & 6 \\
\hline & 80 & Efriyanti & 1 \\
\hline \multirow{13}{*}{ Sedang } & 80 & Yarniati & 2 \\
\hline & 80 & Visnawarni & 3 \\
\hline & 75 & Rice & 4 \\
\hline & 75 & Meri Norman & 5 \\
\hline & 75 & Maijel & 6 \\
\hline & 75 & Mirnawasni & 6 \\
\hline & 70 & Meri wisnu & 5 \\
\hline & 70 & Ernawati & 4 \\
\hline & 65 & Jirman & 3 \\
\hline & 65 & Hari weri & 2 \\
\hline & 65 & Dirlantas & 1 \\
\hline & 65 & Yeniwati & 6 \\
\hline & 65 & Niqita Weli & 5 \\
\hline \multirow{7}{*}{ Rendah } & 60 & Habrurlah & 4 \\
\hline & 60 & Rindu jari & 6 \\
\hline & 60 & Jeri Nenglo & 5 \\
\hline & 60 & Risna Susilo & 4 \\
\hline & 55 & Rian Hardianto & 3 \\
\hline & 50 & Hardimansyah & 2 \\
\hline & 45 & Herman Syahrial & 1 \\
\hline
\end{tabular}

Berdasarkan urutan di atas, diambil satu-satu peserta didik setiap bagian yang menempati angka yang sama untuk menjadi anggota kelompok kooperatif. Selain tingkat akademik , pembagian kelompok ini juga memperhatikan jenis kelamin, tempat tinggal, dan latar belakang sosial yang berbeda. Berdasarkan skor tesebut peserta didik dibagi menjadi 6 kelompok kooperatif yang heterogen (kemampuan akademik dan jenis kelamin yang berbeda). Untuk lebih jelasnya lihat tabel 4.7:

Tabel 6. Nama-nama Kelompok Siklus II

\begin{tabular}{clc}
\hline Nama Kelompok & \multicolumn{1}{c}{ Nama Peserta Didik } & Skor Dasar \\
& Ramawati & $\mathbf{9 0}$ \\
\hline \multirow{2}{*}{ Kancil } & Zizi & $\mathbf{8 0}$ \\
& Aliya & $\mathbf{6 5}$ \\
& Fifiani & $\mathbf{4 5}$ \\
& Defayanti & $\mathbf{8 5}$ \\
& Efriyanti & $\mathbf{8 0}$ \\
Harimau & Yarniati & $\mathbf{6 5}$ \\
& Visnawarni & $\mathbf{5 0}$ \\
& Meri Norman & $\mathbf{8 0}$ \\
& Maijel & $\mathbf{8 0}$ \\
& Mirnawasni & $\mathbf{6 5}$ \\
& Meri wisnu & $\mathbf{5 5}$ \\
& Jirman & $\mathbf{8 0}$ \\
& Hari Weri & $\mathbf{7 5}$ \\
\hline
\end{tabular}




\begin{tabular}{lll}
\hline & Dirlantas & $\mathbf{7 0}$ \\
& Yeniwati & $\mathbf{6 0}$ \\
Kucing & Niqita Weli & $\mathbf{6 0}$ \\
& Rindu jari & $\mathbf{8 0}$ \\
& Jeri Nenglo & $\mathbf{7 5}$ \\
& Risna Susilo & $\mathbf{7 0}$ \\
& Rian Hardianto & $\mathbf{6 5}$ \\
\hline Haga & Hardimansyah & $\mathbf{6 0}$ \\
\hline & Yolanda & $\mathbf{8 0}$ \\
& Herman Syahrial & $\mathbf{7 5}$ \\
& Habrurlah & $\mathbf{7 5}$ \\
& Ernawati & $\mathbf{6 5}$ \\
\hline
\end{tabular}

Selanjutnya guru menjelaskan aturan-aturan dalam kerja kelompok seperti: Meminta anggota kelompok bekerja sama, mengatur meja dan kursi, serta meminta kesempatan selama sepuluh menit untuk memberi nama kelompok mereka. Menganjurkan kepada tiap-tiap kelompok bekerja berpasangan dalam kelompok. Jika peserta didik memiliki pertanyaan, mereka diminta mengajukan pertanyaan tersebut kepada teman satu kelompoknya sebelum menanyakan kepada guru. Memberi penekanan kepada peserta didik bahwa tugas dikerjakan sebaik-baiknya dan akan dinilai, mereka tidak boleh mengakhiri kegiatan belajar sebelum kegiatan berakhir. Kegiatan ini berlangsung selama lima menit. Dalam hal ini guru tidak terlalu lama menjelaskan, karena peserta didik sudah mengerti dan peserta didik mendengarkannya dengan seksama.

Setelah itu guru membagikan LKS dan teks bacaan pada masing-masing kelompok. Setiap kelompok mendapat dua rangkap LKS dan 4 rangkap wacana bacaan. Saat pembagian LKS dan wacana ini peserta didik berebut, karena mereka tidak sabar untuk melihatnya.

Langkah selanjutnya guru menugasi masing-masing kelompok untuk mendiskusikan tugas yang diberikan. Dalam pelaksanaan diskusi kelompok ini guru menegaskan kepada masing-masing anggota kelompok harus menguasai bahan yang didiskusikan, serta mereka boleh menggunakan buku paket IPS yang tersedia untuk membahas materi yang didiskusikan. Oleh karena itu bagi peserta didik yang telah paham mempunyai kewajiban untuk menjelaskan atau membantu temannya yang belum mengerti atau yang belum menguasai bahan. Dalam pelaksanaan diskusi kelompok ini guru terus membimbing dan memotivasi semua kelompok. Dengan demikian sangat terlihat sekali meningkatnya interaksi antara peserta didik, dan mereka sangat antusias dalam berdiskusi.

\section{Pemeriksaan hasil kerja kelompok}

Setelah diskusi kelompok selesai maka langkah selanjutnya guru menugasi perwakilan kelompok untuk melaporkan hasil diskusi kelompoknya, sedangkan kelompok yang lain menanggapi. Pada siklus kedua ini peserta didik sudah tidak takut lagi untuk tampil ke depan kelas untuk membacakan hasil kerja kelompoknya. Dan kelompok yang lain juga sudah menanggapi hasil pembacaan kelompok yang tampil. Setelah setiap perwakilan kelompok melaporkan hasil kerja kelompoknya, baru guru membagikan kunci jawaban LKS. Jika ada jawaban yang salah, maka gurui menugasi peserta didik untuk mencocokkan jawabannya dengan kunci LKS yang dibagikan.

Pada akhir pembelajaran guru bersama peserta didik menyimpulkan materi yang telah dipelajari. Penyimpulan materi ini dilakukan guru dengan memberikan pertanyaan-pertanyaan kepada peserta didik, sehingga peserta didik bersemangat menjawabnya. Sebelum membenarkan jawaban dari peserta didik, guru melemparkan dulu kepada peserta didik yang lainya. Apabila jawaban masih belum tepat baru guru meluruskannya. Langkah selanjutnya guru meminta peserta didik untuk kembali pada tempat duduknya masing-masing.

\section{Tes individual}


Setelah penyimpulan materi pembelajaran, guru memberikan soal kuis/evaluasi kepada peserta didik secara keseluruhan. Soal yang diberikan berupa objektif sebanyak 10 buah dan uraian singkat 5 buah. Tes ini bertujuan untuk mengetahui pemahaman peserta didik terhadap materi yang telah diberikan yaitu peranan para tokoh dalam mempertahankan kemerdekaan. Saat pelaksanaan kuis/evaluasi peserta didik tidak diperbolehkan saling membantu satu sama lainnya.

\section{Pemeriksaan hasil tes}

Setelah peserta didik selesai mengerjakan soal-soal tersebut, maka guru memeriksanya. Dalam menyelesaikan soal tes hanya 3 orang peserta didik masih mengalami kesulitan dalam menjawab soal tes. Hasil tes akhir pada siklus II ini menggambarkan bahwa peserta didik rata-rata sudah menguasai materi. Berikut hasil tes yang diperoleh peserta didik.

Tabel 7. Hasil Tes Akhir Peserta Didik Siklus II

\begin{tabular}{|c|c|c|c|}
\hline \multicolumn{3}{|c|}{ Nama Peserta Didik } & \multirow[b]{2}{*}{ Hasil tes Akhir } \\
\hline No & & Skor Dasar & \\
\hline 1 & Ramawati & 50 & 75 \\
\hline 2 & Zizi & 45 & 50 \\
\hline 3 & Aliya & 65 & 90 \\
\hline 4 & Fifiani & 75 & 95 \\
\hline 5 & Yolanda & 60 & 75 \\
\hline 6 & Defayanti & 80 & 75 \\
\hline 7 & Efriyanti & 60 & 75 \\
\hline 8 & Yarniati & 70 & 75 \\
\hline 9 & Visnawarni & 80 & 100 \\
\hline 10 & Rice & 75 & 80 \\
\hline 11 & Meri Norman & 60 & 80 \\
\hline 12 & Maijel & 80 & 75 \\
\hline 13 & Mirnawasni & 60 & 75 \\
\hline 14 & Meri wisnu & 65 & 65 \\
\hline 15 & Ernawati & 60 & 90 \\
\hline 16 & Jirman & 75 & 95 \\
\hline 17 & Hari Weri & 85 & 85 \\
\hline 18 & Dirlantas & 80 & 80 \\
\hline 19 & Yeniwati & 80 & 80 \\
\hline 20 & Niqita Weli & 80 & 100 \\
\hline 21 & Habrurlah & 65 & 75 \\
\hline 22 & Rindu jari & 80 & 100 \\
\hline 23 & Jeri Nenglo & 70 & 75 \\
\hline 24 & Risna Susilo & 90 & 95 \\
\hline 25 & Rian Hardianto & 65 & 75 \\
\hline 26 & Hardimansyah & 70 & 80 \\
\hline \multirow[t]{3}{*}{27} & Herman Syahrial & 55 & 65 \\
\hline & Jumlah & 1950 & 2180 \\
\hline & Rata-rata & 72,22 & 80,74 \\
\hline
\end{tabular}

\section{Penghargaan kelompok}

Setelah diperoleh hasil tes, maka guru menentukan skor peningkatan yang diperoleh peserta didik berdasarkan selisih antara skor dasar dengan skor tes, kemudian skor peningkatan tersebut dapat digunakan untuk menghitung poin perkembangan yang diperoleh masing-masing peserta didik. Selanjutnya poin perkembangan tersebut dimasukkan ke dalam lembar penilaian kelompok. Bagi kelompok yang memperoleh poin perkembangan berdasarkan kriteria yang telah ditentukan akan mendapat penghargaan. Berikut lembar penilaian kelompok: 
Tabel 8. Penilaian Kelompok padaSiklus II

\begin{tabular}{|c|c|c|c|c|c|}
\hline $\begin{array}{c}\text { Nama } \\
\text { Kelompok }\end{array}$ & $\begin{array}{c}\text { Nama peserta } \\
\text { didik }\end{array}$ & $\begin{array}{c}\text { Skor } \\
\text { Dasar }\end{array}$ & $\begin{array}{l}\text { Skor } \\
\text { Akhir }\end{array}$ & $\begin{array}{c}\text { Poin } \\
\text { Perkembangan }\end{array}$ & Penghargaan \\
\hline \multirow[t]{4}{*}{ Kancil } & Ramawati & 90 & 85 & 20 & KELOMPOK \\
\hline & Zizi & 80 & 75 & 10 & BAIK \\
\hline & Aliya & 65 & 65 & 20 & \\
\hline & Fifiani & 45 & 50 & 20 & \\
\hline Jumlah & & & & 70 & \\
\hline Rata-rata & & & & 17,5 & \\
\hline Cendrawa & Defayanti & 85 & 85 & 20 & KELOMPOK \\
\hline \multirow[t]{3}{*}{ sih } & Efriyanti & 80 & 80 & 20 & HEBAT \\
\hline & Yarniati & 65 & 75 & 20 & \\
\hline & Visnawarni & 50 & 75 & 30 & \\
\hline Jumlah & & & & 90 & \\
\hline Rata-rata & & & & 22,5 & \\
\hline \multirow[t]{4}{*}{ Harimau } & Meri Norman & 80 & 100 & 30 & \\
\hline & Maijel & 80 & 75 & 10 & \\
\hline & Mirnawasni & 65 & 75 & 20 & KELOMPOK \\
\hline & Meri wisnu & 55 & 65 & 20 & HEBAT \\
\hline Jumlah & & & & 80 & \\
\hline Rata-rata & & & & 20 & \\
\hline \multirow[t]{5}{*}{ Singa } & Jirman & 80 & 100 & 30 & KELOMPOK \\
\hline & Hari Weri & 75 & 95 & 30 & SUPER \\
\hline & Dirlantas & 70 & 75 & 20 & \\
\hline & Yeniwati & 60 & 80 & 30 & \\
\hline & Niqita Weli & 60 & 75 & 30 & \\
\hline Jumlah & & & & 140 & \\
\hline Rata-rata & & & & 28 & \\
\hline \multirow[t]{5}{*}{ Kucing } & Rindu jari & 80 & 80 & 20 & \\
\hline & Jeri Nenglo & 75 & 95 & 30 & \\
\hline & Risna Susilo & 70 & 80 & 20 & KELOMPOK \\
\hline & Rian Hardianto & 65 & 90 & 30 & SUPER \\
\hline & Hardimansyah & 60 & 75 & 30 & \\
\hline Jumlah & & & & 130 & \\
\hline Rata-rata & & & & 26 & \\
\hline \multirow[t]{5}{*}{ Naga } & Yolanda & 80 & 100 & 30 & KELOMPOK \\
\hline & Herman Syahrial & 75 & 80 & 30 & HEBAT \\
\hline & Habrurlah & 70 & 75 & 20 & \\
\hline & Ernawati & 65 & 75 & 20 & \\
\hline & Rice & 60 & 90 & 30 & \\
\hline Jumlah & & & & 120 & \\
\hline Rata-rata & & & & 24 & \\
\hline
\end{tabular}

Kegiatan Akhir

Guru mengarahkan peserta didik dalam menyimpulkan materi pembelajaran dengan melakukan tanya jawab tentang materi peranan para tokoh dalam mempertahankan kemerdekaan.

\section{Pengamatan}

Hasil pengamatan terhadap aktivitas guru saat membagi peserta didik dalam kelompok kooperatif yang beranggotakan 4 atau 5 orang guru dinilai sangat baik karena semua deskriptor sudah dilakukan. Kegiatan selanjutnya adalah penyampaian materi tentang peranan para tokoh dalam mempertahankan kemerdekaan dinilai sangat baik karena semua deskriptor sudah dilakukan dalam proses pembelajaran. Pada tahap menjelaskan langkah-langkah kerja kelompok guru dinilai 
sangat baik, karena semua deskriptor sudah dilakukan dalam pembelajaran. Tahap selanjutnya membimbing peserta didik dalam kerja kelompok guru mendapat kualifikasi sangat baik karena semua deskriptor sudah dilakukan.

Aktivitas peserta didik saat pembagian kelompok dinilai sangat baik, karena semua deskriptor sudah dilaksanakan. Pada tahap mendengarkan penyampaian materi tentang peranan para tokoh dalam mempertahankan kemerdekaan, peserta didik sudah serius melakukannya. Ada satu aktivitas peserta didik yang belum dilaksanakan yaitu masih ragu-ragu untuk bertanya. Selanjutnya tahap mendengarkan langkah-langkah kerja kelompok, peserta didik sudah dapat mendengarkannya dengan sangat baik. Peserta didik sudah dapat berdiskusi dalam kelompok dengan aktif. Kemudian tahap melaporkan hasil kerja kelompok, penyimpulan materi pembelajaran, dan penerimaan penghargaan sudah dilaksanakan dengan sangat baik. Saat melakukan kuis/evaluasi peserta didik masih ribut.

Ketuntasan hasil belajar sudah mencapai target yang ditetapkan sebagaimana yang ditetapkan BSNP (2006:12) "ketuntasan belajar setiap indikator yang telah ditetapkan dalam suatu kompetensi dasr berkisar antara $0-100 \%$ dengan kreteria ideal ketuntasan untuk masing-masing indikator 75\%". Untuk lebih jelasnya dapat dilihat pada tabel di bawah ini:

Tabel 9. Ketuntasan Hasil Belajar Peserta Didik pada Siklus II

\begin{tabular}{|c|c|c|c|c|c|c|}
\hline \multirow[b]{2}{*}{ No } & \multirow[b]{2}{*}{ Nama } & \multirow[b]{2}{*}{ Nilai } & \multirow{2}{*}{$\begin{array}{c}\% \\
\text { Ketuntasan } \\
\text { Perorangan }\end{array}$} & \multicolumn{2}{|c|}{ Ketuntasan } & \multirow[b]{2}{*}{ Keterangan } \\
\hline & & & & Tuntas & $\begin{array}{l}\text { Belum } \\
\text { Tuntas }\end{array}$ & \\
\hline 1 & Ramawati & 100 & $100 \%$ & $\sqrt{ }$ & - & \\
\hline 2 & Zizi & 85 & $85 \%$ & $\sqrt{ }$ & - & \\
\hline 3 & Aliya & 95 & $95 \%$ & $\sqrt{ }$ & - & \\
\hline 4 & Fifiani & 95 & $95 \%$ & $\sqrt{ }$ & - & \\
\hline 5 & Yolanda & 95 & $95 \%$ & $\sqrt{ }$ & - & \\
\hline 6 & Defayanti & 100 & $100 \%$ & $\sqrt{ }$ & - & \\
\hline 7 & Efriyanti & 75 & $75 \%$ & $\sqrt{ }$ & - & \\
\hline 8 & Yarniati & 80 & $80 \%$ & $\sqrt{ }$ & - & \\
\hline 9 & Visnawarni & 75 & $75 \%$ & $\sqrt{ }$ & - & \\
\hline 10 & Rice & 100 & $100 \%$ & $\sqrt{ }$ & - & \\
\hline 11 & Meri Norman & 80 & $80 \%$ & $\sqrt{ }$ & - & \\
\hline 12 & Maijel & 75 & $75 \%$ & $\sqrt{ }$ & - & \\
\hline 13 & Mirnawasni & 80 & $80 \%$ & $\sqrt{ }$ & - & \\
\hline 14 & Meri wisnu & 75 & $75 \%$ & $\sqrt{ }$ & - & \\
\hline 15 & Ernawati & 90 & $90 \%$ & $\sqrt{ }$ & - & \\
\hline 16 & Jirman & 75 & $75 \%$ & $\sqrt{ }$ & - & \\
\hline 17 & Hari weri & 80 & $80 \%$ & $\sqrt{ }$ & - & \\
\hline 18 & Dirlantas & 75 & $75 \%$ & $\sqrt{ }$ & - & \\
\hline 19 & Yeniwati & 90 & $90 \%$ & $\sqrt{ }$ & - & \\
\hline 20 & Niqita Weli & 50 & $50 \%$ & - & $\sqrt{ }$ & \\
\hline 21 & Habrurlah & 75 & $75 \%$ & $\sqrt{ }$ & - & \\
\hline 22 & Rindu jari & 75 & $75 \%$ & $\sqrt{ }$ & - & \\
\hline 23 & Jeri Nenglo & 75 & $75 \%$ & $\sqrt{ }$ & - & \\
\hline 24 & Risna Susilo & 65 & $65 \%$ & - & $\sqrt{ }$ & \\
\hline 25 & Rian Hardianto & 80 & $80 \%$ & $\sqrt{ }$ & - & \\
\hline 26 & Hardimansyah & 75 & $75 \%$ & $\sqrt{ }$ & - & \\
\hline 27 & Herman Syahrial & 65 & $65 \%$ & - & $\sqrt{ }$ & \\
\hline Jumlah & & 2180 & & & & \\
\hline Rata-rata & & 80,74 & & & & \\
\hline Persen & & $80,74 \%$ & & $\mathbf{8 8 , 8 9 \%}$ & $11,11 \%$ & \\
\hline
\end{tabular}


Dari data di atas dapat diperoleh gambaran bahwa hasil pembelajaran IPS dengan menggunakan model kooperatif tipe STAD adalah sebagai berikut :nilai tertinggi adalah 100 sebanyak 3 orang, nilai 95 sebanyak 3 orang, nilai 90 sebanyak 2 orang, nilai 85 sebanyak1 orang, nilai 80 sebanyak 5 orang, nilai 75 sebanyak 10 orang, nilai 65 sebanyak 2 orang, dan nilai 50 sebanyak 1 orang. Dari gambaran perolehan nilai tersebut dapat disimpulkan peserta didik yang tuntas adalah 24 orang dan yang belum tuntas adalah 3 orang.

\section{Refleksi}

Dari hasil pengamatan dan diskusi guru dengan observer maka hasil penelitian siklus II ini dapat direfleksikan, bahwa secara umum aktivitas peserta didik dan guru dalam pembelajaran sudah berjalan dengan optimal. Sehingga hasil pembelajaran juga meningkat Semua deskriptor dari setiap karakteristik secara umum sudah terlaksana. Keberhasilan yang telah dicapai pada siklus II ini adalah sebagai berikut:

1. Penggunaan model kooperatif tipe STAD pada materi menghargai perjuangan para tokoh dalam mempertahankan kemerdekaan sudah mencapai keberhasilan.

2. Penggunaan model kooperatif tipe STAD dapat meningkatkan pemahaman peserta didik terhadap pembelajaran dan meningkatkan aktivitas peserta didik dalam proses pembelajaran, seperti Peserta didik tidak merasa canggung lagi untuk bertukar pikiran dan membagi ide dengan teman sekelompoknya, sudah terbiasa dengan berdiskusi kelompok, sehingga interaksi antara peserta didik meningkat, dan suasana kelas lebih hidup.

3. Berdasarkan pengamatan yang dilakukan maka tujuan pembelajaran yang diharapkan pada pembelajaran siklus II sudah mencapai target yang diinginkan.

\section{PEMBAHASAN}

Rancangan pembelajaran disusun berdasarkan langkah-langkah pembelajaran kooperatif tipe STAD. Sesuai dengan pendapat Nurasma (2009:51), tahap-tahap belajar kooperatif tipe STAD adalah:"1) penyajian kelas, 2) kegiatan belajar kelompok, 3) pemeriksaan terhadap hasil kegiatan kelompok, 4) peserta didik mengerjakan soal-soal tes secara individual, 5) pemeriksaan hasil tes, dan 6) penghargaan kelompok". Adapun indikator yang ingin dicapai pada penelitianan tindakan pada siklus I ini adalah (1) menyebutkan bentuk perjuangan bangsa Indonesia dalam mempertahankan kemerdekaan Indonesia, (2) mengidentifikasi peristiwa-peristiwa dalam mempertahankan kemerdekaan Indonesia, (3) menceritakan latar belakang terjadinya usaha dalam mempertahan kemerdekaan, (4) menjelaskan caara menghargai perjuangan para tokoh dalam mempertahankan kemerdekaan. Rencana pelaksanaan pembelajaran dilakukan tiga tahap yaitu kegiatan awal, kegiatan inti, kegiatan akhir. Tahap intinya yaitu penyajian materi, kegiatan belajar kelompok, pemeriksaan terhadap hasil kegiatan kelompok, tes individual, pemeriksaan tes individual, dan penghargaan kelompok. Sedangkan kegiatan akhir dari pembelajaran adalah penyimpulan materi yang telah diajarkan.

Pelaksanaan kegiatan pembelajaran yang dilakukan dimulai dengan menyanyikan lagu yang berkaitan dengan materi yang akan dipelajari yaitu Halo-halo Bandung. Pada saat bernyanyi awalnya peserta didik kurang bersemangat karena kurang hafal syair lagunya. Kemudian guru mengingatkan kembali peserta didik tentang syair lagu dengan cara mencatatkannya dipapan tulis. Setelah itu peserta didik nampak bersemangat dalam bernyanyi karena sudah hafal lagunya. Selanjutnya dilakukan tanya jawab tentang isi lagu. Hal ini penting dilakukan karena pengetahuan dibangun berdasarkan informasi yang diperoleh peserta didik atau pengetahuan yang diperoleh sekarang dengan pengalaman yang dimilikinya.

Membangkitkan skemata peserta didik guru dapat menanyakan pelajaran sebelumnya dan memberikan pertanyaan yang dapat mengarahkan peserta didik pada pembelajaran yang akan dilaksanakan. Selanjutnya guru menyampaikan tujuan pembelajaran, agar peserta didik mengetahui apa yang harus dikuasai setelah melaksanakan pembelajaran. Dengan demikian pikiran peserta didik dapat terfokus terhadap materi yang didiskusikan. Oleh sebab itu menyampaikan tujuan pembelajaran yang jelas dapat mengarahkan peserta didik terhadap materi yang harus dikuasai setelah kegiatan berlangsung. 
Saat penyajian materi ini, guru menggunakan media gambar tentang bentuk pertempuran yang dilakukan para pejuang dalam mempertahankan kemerdekaan. Untuk menggali pengetahuan peserta didik tentang gambar yang dipajang, guru meminta peserta didik yang terlebih dahulu menceritakan gambar yang dipajang. Namun peserta didik banyak yang merasa takut dan malu untuk menceritakan, karena mereka belum terbiasa. Untuk menghilangkan rasa takut dan rasa malu peserta didik maka guru melakukan tanya jawab. Dengan tanya jawab tersebut peserta didik mulai berani mengeluarkan pendapatnya.

Setelah itu, guru terlebih dahulu membagi peserta didik dalam beberapa kelompok kooperatif yang terdiri dari 5-6 orang peserta didik yang mewakili seluruh bagian kelas dalam hal kinerja akademik, jenis kelamin, ras, dan etnisitas. Fungsi utama dari kelompok ini adalah untuk memastikan bahwa semua anggota kelompok benar-benar belajar, dan lebih khususnya untuk mempersiapkan anggotanya untuk bisa mengerjakan tes dengan baik.

Setelah kelompok kooperatif terbentuk guru meminta peserta didik duduk dalam kelompoknya masing-masing. Saat pembagian kelompok ini suasana ribut karena peserta didik sibuk mengatur tempat duduk dan mencari teman kelompoknya. Selanjutnya guru membagikan lembar tugas, teks bacaan, dan lembar kunci jawaban masing-masing dua rangkap untuk setiap kelompok, tujuannya agar terjalin kerja sama di antara anggota kelompok. Lembar tugas dan teks bacaan dibagikan pada saat kegiatan belajar kelompok, sedangkan kunci jawaban diserahkan setelah kegiatan kelompok selesai dilaksanakan. Setelah menyerahkan lembar tugas dan teks bacaan, guru menjelaskan tahap-tahap dan fungsi belajar kelompok dari tipe STAD.

Setelah diskusi kelompok berakhir, kegiatan selanjutnya guru meminta perwakilan kelompok untuk membacakan hasil diskusi kelompoknya di depan kelas dan kelompok yang lain menanggapinya. Sebelum pembacaan hasil kerja kelompok dilakukan, guru meminta pada masingmasing kelompok untuk mendiskusikan perwakilan dari kelompoknya yang akan membacakan hasil diskusinya. Guru mendatangi setiap kelompok untuk memastikan apakah masing-masing kelompok sudah memilih perwakilan kelompoknya untuk membacakan ke depan kelas. Saat pembacaan hasil kerja kelompok, peserta didik terlihat malu-malu dan mengalami kesulitan karena mereka belum terbiasa dengan kegiatan tersebut, serta mereka merasa takut akan dicemoohkan oleh teman-temannya.

Tes individual dilakukan untuk melihat kemampuan peserta didik dalam memahami materi yang telah dipelajari. Soal yang diberikan berupa objektif sebanyak 10 buah dan essay 5 buah. Dalam menjawab soal-soal peserta didik tidak boleh bekerja sama dan melihat buku. Tahap selanjutnya adalah pemeriksaan hasil tes. Pemeriksaan hasil tes ini guru lakukan setelah habis jam pembelajaran. Hasil tes yang diperoleh pada siklus I masih jauh dari target yang ditetapkan. Hal ini terlihat dari 27 orang peserta didik hanya 13 orang yang tuntas dan 14 orang yang belum tuntas. Sedangkan rata-rata kelas yang dicapai baru 72,22. Setelah diperoleh hasil tes, maka guru menentukan skor peningkatan yang diperoleh peserta didik berdasarkan selisih antara skor dasar dengan skor tes, selanjutnya skor peningkatan tersebut digunakan untuk menghitung poin perkembangan yang diperoleh masing-masing peserta didik.

Kegiatan penghargaan kelompok dilakukan setelah peserta didik selesai mengerjakan tes dan guru menghitung poin perkembangan yang diperoleh masing-masing peserta didik. Setelah poin perkembangan diperoleh kemudian guru memasukkan poin tersebut ke dalam lembar penilaian kelompok. Berdasarkan lembar penilaian kelompok tersebut guru memberikan penghargaan untuk kelompok yang berhasil memperoleh predikat super, tim hebat, dan tim terbaik. Untuk tim super skor rata-ratanya adalah lebih atau sama dengan 25 poin. Tim hebat $16-25$ poin, sedangkan 5-15 poin adalah tim terbaik. Bentuk penghargaan yang guru berikan adalah berupa piagam penghargaan. Akhir dari pembelajaran, peserta didik dengan bimbingan guru menyimpulkan materi yang telah dipelajari.

Pada tahap ini guru menemukan hasil akhir kegiatan pembelajaran yang berupa penilaian. Hal ini sejalan dengan pendapat Nawawi (dalam Theresia, 2007:3) mengemukakan" hasil belajar dapat diartikan sebagai tingkat keberhasilan peserta didik dalam mempelajari materi pelajaran di 
sekolah yang dinyatakan dalam skor yang diperoleh dari hasil tes mengenai sejumlah materi pelajaran tertentu".

\section{KESIMPULAN}

Berdasarkan data hasil penelitian dan pembahasan tentang upaya peningkatan pembelajaran IPS dengan menggunakan model kooperatif tipe STAD dapat disimpulkan sebagai berikut:

1. Kegiatan perencanaan disesuaikan dengan langkah-langkah pembelajaran Model Kooperatif tipe STAD. Selain itu juga menyiapkan media dan alat yang sesuai dengan materi agar peserta didik dapat termotivasi dalam belajar.

2. Penggunaan Model Kooperatif tipe STAD pada mata pelajaran IPS dapat meningkatkan hasil belajar peserta didik.

\section{SARAN}

Saran yang dapat diberikan berdasarkan kesimpulan di atas adalah:

1. Perencanaan pembelajaran yang dirancang sebaiknya disesuaikan dengan situasi nyata peserta didik.

2. Penggunaan model pembelajaran kooperatif tipe STAD ini sebaiknya diikuti dengan menggunakan media pembelajaran yang tepat.

3. Guru perlu memberikan perhatian, bimbingan dan motivasi belajar secara sungguh-sungguh kepada peserta didik yang berkemampuan kurang dan pasif dalam kelompok, karena peserta didik yang demikian sering mengantungkan diri pada temannya.

\section{DAFTAR RUJUKAN}

DEPDIKNAS. 2006. Kurikulum Tingkat Satuan Pendidikan. Jakarta: DEPDIKNAS.

DEPDIKNAS. 2008. Ketentuan Kegiatan Tengah Semester dan Sistem Penilaian di SD/MI

Ischak SU, dkk. 1997. Materi Pokok Pendidikan IPS di SD. Jakarta: Depdikbud.

Oemar Hamalik. 2005. Kurikulum dan Pembelajaran. Jakarta: Bumi Aksara.

Oemar Hamalik. 2008. Ketentuan Kegiatan Tengah Semester dan Sistem Penilaian di SD/MI.

Suharsimi Arikunto. 2005. Dasar-dasar Evaluasi Pendidikan. Jakarta: Bumi Aksara.

Wina Sanjaya. 2008. Strategi Pembelajaran Berorentasi Standar Proses Pendidikan. Jakarta: Kencana Prenada Media Group. 